\title{
Modinomics: Design, Implementation, Outcomes and Prospects
}

\section{Raghbendra Jha*}

\begin{abstract}
The present paper presents an analysis of the key elements of Modinomics, defined as “everyone's participation, everyone's progress." It investigates the reasons why Modinomics was necessary, the key elements of Modinomics, and how this policy was implemented, as well as two deep structural reforms under Modi. The paper examines the record of economic growth under Modi as well as new welfare and employment programs to make economic growth more inclusive. Finally, the paper examines medium and long -term growth prospects for India.
\end{abstract}

Keywords: Modinomics, economic growth performance, demonetization, GST, welfare programs

JEL Classification Codes: O00, O10, O50, Q01,

Arndt-Corden Department of Economics, College of Asia and the Pacific, Coombs Building (09), Australian National University, Acton ACT 2601, Australia Phone:+61-2-6125 2683, Email: r.jha@anu.edu.au

\footnotetext{
* I am grateful to the Japan Center for Economic Research for their kind invitation to prepare and present
} this paper. All views are my own. 
"I want to run the government professionally. Secondly, the biggest crisis in the country is lack of trust, crisis of stagnancy, where we need to give some momentum. If we start all this everything will fall into place."

Prime Ministerial Candidate Narendra Modi in an interview on April 17, 2014

Available at https://www.narendramodi.in/i-want-to-run-the-government-professionallynarendra-modi-3173

Accessed $19^{\text {th }}$ February 2018.

\section{Introduction: What is Modinomics?}

Preceding his election as Prime Minister (PM) of India in May 2014 the term "Modinomics" was used to describe the economic policies that the incoming PM would adopt to ensure that India returned to the high growth trajectory that it had enjoyed in the early 2000s. This higher projected growth would be more inclusive because, through good governance, the benefits of such growth would reach very large sections of society, maintain macroeconomic stability and be environmentally friendly. This approach was summarised in the widely used election slogan "sabka saath, sabka vikas" “everyone's participation, everyone's progress". Panagariya (2018) considers this slogan to be the essence of Modinomics. ${ }^{1}$ Complementary slogans are "Maximum governance and minimum government", "Decentralization and cooperative federalism" and "Enhanced Connectivity" be it digital/rail/road or air connectivity. In essence, then, Modinomics implies a strategy of participatory development.

When Modi became PM this participatory development was portrayed as a multifaceted strategy and was broadly based on Modi's successful tenure as Chief Minister of the state of Gujarat (2001 to 2014). The various components of this strategy can be grouped under three broad headings: (i) restoration of trust in government and the public policy process, (ii) creation of conditions for rapid economic growth with macroeconomic stability and increased participation by the masses, and (iii)

\footnotetext{
${ }^{1}$ Panagariya was the first deputy chairman of the Niti Ayog, the policy making body that replaced the Planning Commission.
} 
ASARC Working Paper 2018/02

implementing deep structural reforms designed to place the economy on a higher more inclusive growth track for the medium term.

This paper purports to be an analysis of the key elements of Modinomics. It investigates the reasons why Modinomics was necessary (section II); the key elements of Modinomics and how this policy was implemented (section III); and structural reforms under Modi (section IV). Section V examines new employment and welfare programs. Section VI looks at medium and long-term prospects for India and concludes.

\section{The necessity of Modinomics}

Although Manmohan Singh as Finance Minister is credited with initiating India's 1991 reforms, his record as Prime Minister was less glowing. This underscores the importance of having political support to back deep structural reforms. Without then Prime Minister Rao's backing Manmohan Singh would not have been able to accomplish much. ${ }^{2}$ It is common knowledge that Manmohan Singh wielded little political authority as Prime Minister. That privilege lay with then Congress President Sonia Gandhi (Baru, 2014).

The economy continued to do well in the first term of Singh's Prime Ministership, largely as a result of the momentum it had gathered during Vajpayee's term as PM (1998-2004), which Singh did not disturb, and because the world economy was growing fast. However, during Singh's second term, several policy errors occurred. I discuss some of these policy errors.

In 2012 the Income-tax Act was amended to grant the government powers to tax deals with retrospective effect. This law was used to raise a total tax demand of ₹ 200 billion on UK's Vodafone for its 2007 purchase of Hutchison Whampoa Limited's Indian assets. Predictably, this tax had an adverse effect on both domestic and foreign investment. Second, in the aftermath of the credit freeze following the Global Financial Crisis (GFC), the government considerably pressurised public sector banks to lend whence some prudential norms were sacrificed leading to considerable weakening of these banks' balance sheets, a problem that persists to this day, albeit in much reduced form. Third, the Land Acquisition Act of 2013 made future acquisition of land by the

\footnotetext{
${ }^{2}$ To quote Baru (2016) “Gandhi made Nehru. PV (Narasimha Rao) made Manmohan (Singh)” pp. 81
} 
government difficult. Fourth, the government denied environmental clearances on a routine basis for infrastructure and other projects. Fifth, as described in Jha (2018a) the government was paralysed by the unearthing of several major corruption scandals at the highest levels. ${ }^{3}$ A major concern was the large illegal capital outflow from the country. ${ }^{4}$ The situation was described as "policy paralysis".

As consequences of these lapses key macro parameters started slipping. The fiscal deficit, which had averaged between 2.5 to $4 \%$ of GDP between 2004-05 and 2007-08, rose to 4.5 to $6.5 \%$ between 2008-09 and 2012-13 (Panagariya, 2018). Apart from the fiscal stimuli following the GFC, the government undertook sharp increases in expenditure to address a drought in 2009, expenses related to the general election of 2009 and the expansion of the Mahatma Gandhi National Rural Employment Guarantee Program (MGNREGP) from the poorest 200 districts to the rest of the country.

Although growth rates had started to pick up in 2009, the government kept up the pace of fiscal stimuli on the pretext of combating the effects of the GFC. GDP growth rate fell for six consecutive quarters starting in the third quarter of 2010-11 and did not pick up adequately even until the last year of the UPA regime.

All these factors combined to make the Congress-led United Progressive Alliance (UPA) government unpopular in its second term of office. In the ensuing 2014

Parliamentary elections the Congress Party could win only 44 seats out of the 543 in the Lok Sabha (Lower House of Parliament) for which elections were held. The UPA, including the Congress, won 59 seats. This was the worst electoral performance by the Congress and the the party could not even get the status of an official opposition party. ${ }^{5}$ In stark contrast, the Bharatiya Janata Party (BJP) won 282 seats (a majority) and the National Democratic Alliance (NDA), of which BJP was a constituent, won 336 seats. For the first time in 30 years, India had a majority government. ${ }^{6}$ Apart from the unpopularity of the Congress and its UPA allies voters were attracted to the BJP

\footnotetext{
${ }^{3}$ Some of these scandals are still being exposed. See, for instance, https://timesofindia.indiatimes.com/business/india-business/8020-gold-scheme-row-all-you-need-toknow/articleshow/63171137.cms Accessed 12 March 2018.

${ }^{4}$ Jha and Truong (2015) computed that in 2008 alone nearly \$40 billion was illegally sent out of India through trade misinvoicing.

${ }^{5}$ The official opposition party in India needs to win at least $10 \%$ of the seats in the Lok Sabha, i.e., 54 seats.

${ }^{6}$ The previous majority government was led by Rajiv Gandhi who was Prime Minister during 1984-89.
} 
ASARC Working Paper 2018/02

because of the good performance of the Gujarat government where Modi was Chief Minister.

\section{Constituents of Modinomics}

The first major constituent of Modinomics, as applied in practice and as foreshadowed in the epigraph, was restoration of trust in government. The new government faced an emergent legal situation when it was sworn in. The Supreme Court of India (SCI) had directed the government to form a Special Investigating Team (SIT) to dig out illegal held money including that component which had been transferred abroad. The previous UPA government had not moved on this and $27^{\text {th }}$ May 2014 was the SCI imposed deadline for setting up the SIT. Modi was sworn in as PM on $26^{\text {th }}$ May and, at the first meeting of the new cabinet, on $27^{\text {th }}$ May, this SIT was constituted. It holds regular meetings and reports directly to the SCI.

Many of the corruption scandals unearthed during Singh's government had to do with non-transparent functioning of government; in particular, the new government inherited issues with respect to disbursal of coal mining licenses and spectrum allocations. The new government has since made it mandatory to allocate such licenses through transparent auctions. The new government was quickly able to realize $\$ 45$ billion from transparent coal and e-spectrum auctions. The SCI had earlier cancelled UPA government's allocations of these licenses. Substantial portions of the proceedings from coal auctions were transferred to the states in which the coalmines were located as steps towards decentralized administration. High-level corruption at central government level is almost unheard of today. India was the second least corrupt country in South Asia (behind only Bhutan), according to the Transparency International's Corruption Perceptions Index (CPI) conducted in 2015 (Table 1). This has generated a climate of trust. However, corruption at lower levels of government is still an issue.

Table 1 here.

During 2012 and 2013, the CPI was stagnant in India although India's rank improved because some other countries became more corrupt. Between 2014 and 2016, there was an improvement in the CPI; India's rank improved until 2015. 
ASARC Working Paper 2018/02

In an effort to cut tax evasion, India signed treaties for sharing of tax information with all BRICS nations, the G20 nations, Switzerland and some other countries. This sharing of information has already yielded results in the recouping of some lost tax revenue and increasing prosecution of tax evaders, e.g., on $20^{\text {th }}$ February 2018 the Income Tax Department sent notices of assessment to 200,000 individuals who had deposited more than ₹ 2 million each in their accounts in the aftermath of demonetization.

A second major constituent of Modinomics is simplifying governance and making it more effective. Decentralization and devolution of power were key. Several steps were taken to achieve this. First, the old Planning Commission, which was responsible only to the PM and not to Parliament but yet had considerable financial powers was disbanded. This was replaced by the Niti Ayog (NITI $=$ National Institute for Transformation of India, Ayog = Commission) which is more of an advisory body and works with the cooperation of both the central and state governments.

Furthermore, the $14^{\text {th }}$ Finance Commission (FC) whose recommendations (valid for five years) became operational on $1^{\text {st }}$ April 2015 made several strides in financial decentralization. First, it increased the share of the central government's tax revenues to be distributed to states from $32 \%$ to $42 \%$, the largest increase in the history of India. Next, the sharing pattern of the financing of Centrally Sponsored Schemes was altered so that the state governments had a greater share in the financing and management of these schemes, thus ensuring efficient utilization of public resources.

Third, the share of untied grants in state government transfers to local bodies and Panchayats was raised substantially. Also, provision was made for $100 \%$ compensation for five years for revenue loss by states when the country switched over to the Goods and Services Tax (GST) scheme of indirect taxation.

Fourth, the $14^{\text {th }} \mathrm{FC}$ recommended the establishment of an independent Fiscal Council to undertake ex-ante assessment of fiscal policy implications of budget proposals and their consistency with fiscal policy and rules. Suitable amendment of the Electricity Act 2003 to facilitate levy of penalties for delays in payment of subsidies by the State Governments was recommended. 
ASARC Working Paper 2018/02

Fifth, the FC required establishment of independent regulators for road sector for tariff setting, quality regulation, among other functions. Further, several recommendations were made for evaluating government's ownership, disinvestment in Central Public Sector Enterprises. Thus, the $14^{\text {th }}$ Finance Commission carried out a fundamental restructuring of federal finances.

Some consequences of this improved governance were: between March and June 2015 work on 42 hitherto stalled projects worth US \$17.1 billion resumed. By May 2016 the government had scrapped 1,159 archaic laws (mostly from the colonial era) compared to 1,301 laws that had been repealed in the previous 64 years.

With stagnant savings and investment, high interest rates and sluggish export growth, the momentum to boost the rate of economic growth in India was largely provided by productivity enhancement following improved governance by Modi's administration. Foreign direct Investment (FDI) rules were considerably simplified and large sectors were opened up to FDI, including $100 \%$ FDI in defence.

Following from the aforementioned policies of decentralisation and increased devolution an era of cooperative federalism has been created with states having enhanced resources and able to compete against each other for investment and other opportunities whereas, concurrently, cooperating with each other in major national pursuits like the smooth adoption of the $\mathrm{GST}^{7}$ and expenditure harmonization across levels of government. The development of digital platforms to smoothen processes across governance projects continues on an ever-expanding scale. Transactions digitized include those in the financial sector, tax reporting and payment, the health sector, the education sector and several others. The fact that an overwhelming majority of Indians operate mobile phones makes such transactions more attractive. Transactions through Unified Payments Interface (UPI) including Bharat Interface for Money (BHIM App) have recorded high rates of growth (occasionally double digit growth month on

\footnotetext{
${ }^{7}$ Some argue that as Chief Minister of Gujarat, Modi had opposed the GST but has been a strong advocate of this tax reform as Prime Minister. Since the GST is a destination-based tax predominantly manufacturing states such as Gujarat and Tamilnadu were opposed to it unless they could be compensated for any revenue loss. The erstwhile UPA government was not trusted to do this whereas all states trusted the Modi government to fulfil such obligations.
} 
month) since December 2016 when they became popular in the face of demonetization. Digital penetration is rapidly increasing in India. ${ }^{8}$

Consequently, India has recorded sharp improvements in the World Bank's Ease of Doing Business Index (Table 2)

\section{Table 2 here.}

Table 2 reports Distance to Frontier (DTF) where the frontier is the best practice (greatest ease of doing business, value 100). The closer is a country's ease of doing business to the frontier the higher is its ease of doing business index. Table 2 also ranks countries according to the ease of business conditions prevailing there: the lower the rank the easier it is to conduct business. Since 2015, India's rank has steadily improved and reached 100 in 2018. The index itself has also increased continuously. India does particularly well in the area of getting electricity connection and protecting the interests of minority investors. However, India lags behind in areas such as registering property and enforcing contracts. In November 2017, Moody's raised India's sovereign rating from Baa3 to Baa2 for the first time since 2004.

These and other efforts provided space for the normal functioning of monetary and fiscal policy and facilitated some deep-rooted structural reforms. This stable policy environment facilitated the formation of a Monetary Policy Committee consisting of six members - three from the RBI and three academics. RBI decisions are now taken by majority vote in this committee with the Governor having the authority to break a tie. A policy of flexible inflation targeting was adopted - the flexibility deemed necessary to maintain relatively stable exchange rates. The FC has enjoined the government to maintain the fiscal deficit at about $3 \%$ of GDP starting 2016-17. This target has been marginally overshot. In 2017-18 this was expected, essentially because the government received GST revenues for only 11 months in this financial year but has resolved to cut down the public debt to $40 \%$ of GDP.

\footnotetext{
${ }^{8}$ For the spread of digitization in health sector see https://mohfw.gov.in/ Accessed 1 March 2018.
} 
ASARC Working Paper 2018/02

Consequently, the macro parameters of the Indian economy improved significantly from the time of the UPA government (Table 3).

\section{Table 3 here.}

Among other statistics, table 3 shows growth in real Gross Value Added (GVA) and GDP (GVA + indirect less indirect subsidies = GDP). All data reported use 2011-12 prices as base. The growth rate of GVA and GDP were both well below $7 \%$ each in 2012-13 and 2013-14, although there were small accelerations in both in 2013-14. In 2014-15 growth rates accelerated further and in 2015-16 they were both above $8 \%$. Growth rates dropped in 2016-17 and 2017-18 in light of two major structural reforms (demonetization of high denomination currency notes in November 2016 and the implementation of the GST on $1^{\text {st }}$ July 2017). Nevertheless, growth rates were higher than in 2012-13 and 2013-14. The economy adjusted rapidly to these twin shocks and GDP growth rate in 2018-19 is forecasted to be in the range of 7 to $7.5 \%$. The IMF and ADB have forecasted a growth rate of $7.4 \%$. The IMF forecasts Indian growth rate to top $8 \%$ by 2022 . With an annual population growth rate of $1.2 \%$, GDP per capita is also growing sharply. Both savings and capital formation, although high by traditional Indian standards, are stagnant. The fiscal deficit was above $4 \%$ of GDP until 2014-15 but has fallen since. A long period of high interest rates $^{9}$ has assured that CPI inflation has fallen steadily. The current account deficit at more than $5 \%$ of GDP in 2012-13 was high but has fallen steadily since then before rising marginally in 2017-18. The latest rise is partly because of the adjustment of exporters to the new GST regime.

\section{Increased public participation in economic activity}

Quite early in his term as PM Modi vigorously promoted the adoption of unique identification cards (Aadhar) for all Indian residents. This was used for various purposes including the world's largest program of financial inclusion -the large scale opening of bank accounts through the Prime Minister's Jana Dhana Yojana (JDY). This program is designed to ensure financial services, namely savings accounts, remittance, credit, insurance, pension in an affordable manner. Zero balance bank accounts are permitted.

\footnotetext{
${ }^{9}$ The current RBI repo rate is $6 \%$.
} 
ASARC Working Paper 2018/02

These and other bank accounts of every individual were then linked to their aadhar card and to their Permanent Account Numbers (PAN) for income tax payers.

The scheme has been a great success. As of $16^{\text {th }}$ February 2018310.7 million JDY accounts were operating in the country with a combined balance of ₹ 745.34 billion. Since these (and all other) bank accounts are linked to the Aadhar cards, these bank accounts can also be used for direct deposit of government transfers. As of February 2018 transfers in as many as 412 government programs were being made through Direct Benefit Transfers (DBT) into bank accounts saving the government ₹ 570 billion in administrative costs to date and ensuring better targeting. Since the JDY program was about a host of financial benefits it helped Prime Minister Modi establish his image as a leader of the masses.

To complement the policy of decentralization and devolution the government has embarked on an ambitious program of increasing connectivity (Table 4).

Table 4 here.

The upper panel of Table 4 provides data on increases in railway tracks since 2011-12, i.e., new railway lines, gauge conversion from metre gauge to broad gauge and doubling of railway tracks. There has been a sharp increase in all these categories.

The improvement in road construction has been equally impressive. The lower panel of Table 4 shows progress in construction of national highways and roads under the Prime Minister's Gram Sadak Yojana (Prime Minister's Village Roads plan). The increase in road length per day in 2016-17 was nearly twice that in 2012-13. Funds released to states for road construction have almost quadrupled over this period. In March 2017 India had 4.7 million $\mathrm{km}$. of roads - the second highest in the world. In a novel policy initiative, the government has decided to monetize its assets in order to get additional funds for investment in infrastructure. Thus, Australia's Macquarie bank was successful 
in its bid to Toll, Operate, Transfer (TOT) nine national highways totalling nearly 700 $\mathrm{km}$. The bid was worth ₹96.81 billion. ${ }^{10}$

Phone connectivity is also increasing rapidly. As of December 2017 India had 1.19 billion phones. Air connectivity has also gone up at very high rates. Thus, in February 2017 domestic airlines carried over 8.23 million passengers. The growth rate of passenger traffic was 23 per cent in 2016-17 following from 21.24 per cent in the previous financial year. In 2016-17 international passenger traffic increased by 7.72 per cent.

Freight Traffic grew at a Cumulative Annual Growth Rate (CAGR) of 7.08 per cent over FY06-17. Freight Traffic is expected to grow at a CAGR of 7.27 per cent to reach 4.14 million tonnes in FY23.A regional connectivity scheme named UDAN has been launched to make flying affordable. The airport sector is now open for participation by private parties under the Public-Private-Participation model. The Airports Authority of India aims to bring around 250 airports under operation across the country by 2020 .

\section{Structural Reforms under Modinomics}

Apart from the incremental reforms discussed above the Modi government pursued two deep structural reforms in an effort to place the economy on a more transparent, inclusive and faster growth path in the medium term. The first policy (announced on $8^{\text {th }}$ November 2016) was demonetization of currency of large denominations ( $₹ 500$ and $₹ 1,000$ ). The second was the transition to a full-scale GST, which occurred on $1^{\text {st }}$ July 2017. Both reforms were announced after the economy's growth performance had recovered sufficiently during 2015-16 and 2016-17.

\section{Rationale For Demonetisation and GST}

There is no gainsaying the fact that prior to November 2016 India had a very large informal economy. A key indicator of this was the large proportion of transactions carried out using cash: the 2015 currency to GDP ratio was $12.51 \%$ for India, compared

\footnotetext{
${ }^{10} \mathrm{See}$ https://economictimes.indiatimes.com/news/economy/infrastructure/macquarie-wins-maidenbundle-of-road-projects-under-tot-for-rs-9682-crore/articleshow/63116601.cms (Accessed 1 March 2018).
} 
to $9.34 \%$ (China), $7.38 \%$ (US), $4.15 \%$ (Australia), $4.07 \%$ (UK) and $2.45 \%$

(Norway). In 2015, demand deposits as a percentage of currency were 0.6 in India, 20.97 (UK), 5.27 (Euro area) and 3.94 (Australia).

India had a large parallel underground (or black economy) with malefic and dangerous overtones (including diversion to money laundering, drug trafficking and terrorist activity). The counterfeiting and circulation of large denomination currency notes on a large scale only exacerbated the problem. The RBI had warned the public repeatedly about this danger. ${ }^{11}$

India unearthed more than \$1billion in illegal cash holdings from more than 200,000 shell companies post demonetisation. ${ }^{12}$ This Bloomberg report also cites McKinsey \& Co. to suggest that in 2013 India's black economy was nearly $30 \%$ of GDP. Clearly, the situation was unsustainable and had to be addressed.

The gains from moving towards electronic modes of payment and reducing the use of cash are compelling. Electronic payments and transfers provide an easy audit trail for governments to tax individuals and businesses and track illegal transactions such as money laundering, financing of crime, terrorism and drug smuggling. No wonder, some governments (e.g. Denmark), routinely discourage the use of currency notes ${ }^{13}$.

\footnotetext{
${ }^{11}$ https://rbi.org.in/scripts/BS PressReleaseDisplay.aspx?prid=38415. Accessed $12^{\text {th }}$ $\underline{\text { March } 2018}$
}
${ }^{12} \mathrm{https}$ ://www.bloomberg.com/news/articles/2017-10-24/india-s-crackdown-on-shell- companies-set-to-intensify-minister Accessed $29^{\text {th }}$ October 2017.

${ }^{13}$ (http://splinternews.com/the-government-of-denmark-wants-people-to-stop-using-ca-1793847623 Accessed $5^{\text {th }}$ January 2018. 
Businesses too benefit from a move away from cash transactions to e-transactions. Evidence from Australia suggests that people spend more when paying electronically. ${ }^{14}$

Electronic means of payment provide greater security of transactions despite the threat of cybercrime. Carrying large amounts of cash involves large risks of its own and fuels government inefficiency and corruption. One report suggests that carrying out transactions by cash actually hurts the poor more than the rich, since it is harder to protect cash against theft, decay, and natural disasters. ${ }^{15}$ Rogoff (2016) argues that reducing the role of cash in the economy improves the efficacy of anti-recessionary monetary policy.

Some have argued that since of the ₹15,440 trillion worth of crore currency denotified all but ₹ 160 billion came back into the banking system demonetisation was a failure. This argument is wrong. All bank deposits have enough information to identify the depositor. Large depositors can be/and are being pursued to check their legitimacy. A report ${ }^{16}$ reveals that the Central Board of Direct Taxes (CBDT) had discovered unexplained cash worth ₹ 3 trillion in bank accounts. Thus, all that the large proportion of denotified currency returning to bank accounts reveals is that the Indian banking system was working well during demonetization.

The value of notes to be disallowed accounted for a huge proportion of total currency value had risen from $36 \%$ of total notes in circulation in 2004 to over $86 \%$ at the time of demonetization. This was the result of a flawed currency policy of the RBI.

14

https://www.treasury.gov.au/ /media/Treasury/Consultations\%20and\%20Reviews/Cons ultations $/ 2016 / \mathrm{Credit} \% 20 \mathrm{card} \% 20 \mathrm{reforms} / \mathrm{Key} \% 20 \mathrm{Documents} / \mathrm{PDF} / \mathrm{Credit}$ card_refor ms_CP.ashx Accessed $5^{\text {th }}$ January 2018.

${ }^{15}$ (http://business.time.com/2012/05/22/how-cash-keeps-poor-people-poor/) Accessed $5^{\text {th }}$ January 2018.

${ }^{16} \mathrm{http} / / / \mathrm{economictimes}$.indiatimes.com/news/economy/policy/cbdt-chief-tells-taxofficers-to-target-rs-3-lakh-crore-unexplained-cash-deposits-during-noteban/articleshow/60876158.cms Accessed 29th September 2017. 
The people had been well prepared for demonetization. The opening of large number of JDY and other bank accounts ensured that that ordinary people had an avenue to deposit all their invalid notes. By announcing a generous amnesty scheme for tax dodgers well before November 2016 the government ensured that those who wanted to come clean on their financial affairs had an opportunity to do so. Thus, the policies were sequenced right: the only people who were indulging in illegal transactions would lose from demonetization. By December 2017 the currency GDP ratio had fallen to $9 \%$.

The second major structural reform was the implementation of the GST. Bagchi (2002) had described India's indirect tax as perhaps the most complex in the world. Jha (2018 $b$, chapter 5) provides an overview of the complexities of the indirect tax system and the inefficiencies therein. In particular, there was the issue of multiplicity of state level indirect taxes and the subsequent cascading of taxes (tax on tax). This also built in disincentives for exports and for domestic investment partly because state-level tax barriers made it difficult for goods to flow smoothly through the country. Contributing to this was a provision of India's constitution that did not allow for cohabitation of the same tax base by both central and state governments. The economy adjusted relatively smoothly to the GST. The sharp reduction in the size of the informal economy through demonetization facilitated the implementation of the GST as the presence of a large informal sector could create a welfare loss. Without demonetization, GST could not succeed.

Value Added Tax (VAT, the GST's predecessor) applied in an economy with a large informal sector (like India's) introduces a strong distortion between the formal and the informal sectors of the economy and hence reduces welfare (Emran and Stiglitz, 2005). This is in contrast to tariff reduction (another indirect tax reform), which reduces distortions between the home economy and the international economy and could improve welfare. Thus, the policies had to be sequenced right - first demonetization and then the GST. The VAT was introduced into India on 1 April 2005 and indirect tax revenues were stagnant in response. Centre and state indirect tax revenue as a percentage of GDP were basically stagnant between 2005-06 and 2010-11 ${ }^{17}$, although economic growth rates were high (average annual growth rate between 2005-06 and

\footnotetext{
${ }^{17} \mathrm{http}$ ://ea.gov.in/sites/default/files/IPFStat201415.pdf Accessed $5^{\text {th }}$ January 2018.
} 
2007-08 was $9.4 \%$. The evidence above does not quantify the welfare losses that may have occurred due to VAT induced distortions.

\section{Some benefits of Demonetization and GST}

Another major spinoff from the dual policies of demonetization and GST has been the sharp increase in tax revenue and number of taxpayers (both direct and indirect taxes). Indian tax/GDP ratio is lower than that of many countries with comparable Per capita GDP in PPP terms. Many areas urgently need public expenditure and the higher tax revenue will facilitate this. The dual policies of demonetization and GST have also led to increasing tax revenues for $2016-17,2017-18^{18}$ and $2018-19 .{ }^{19}$

The GST has many advantages - avoiding of cascading effects of taxes, removing disincentives against exports, creating a unified Indian market - to mention just a few. The last of these advantages is particularly important. With a unified indirect tax structure across the country, finally investors (domestic and foreign) have a strong incentive to invest in India. With this in place, the most important reason for potential slowing down of economic growth (sluggish private investment) will lose some of its bite and economic growth should accelerate in the medium term.

Van Leemput (2016) shows that India has more to gain from internal liberalization than external liberalization. She estimates that if internal trade barriers were reduced to the level of internal trade barriers in the US, welfare in India would increase by $16 \%$ as opposed to only $7 \%$ for international trade liberalization. It stands to reason. For an economy like, say, Thailand external liberalization is very important. In the case of India, however, the economies of only a few states combined are of approximately the same size as that of Thailand's. Removing internal trade barriers is a major policy imperative for India, as this would facilitate gains from trade for all states. The gravity model of trade would predict that the close geographical proximity of the states compared to foreign markets would lead to much larger gains from an expansion and

\footnotetext{
${ }^{18}$ See http://www.livemint.com/Politics/cH5gNYLvx0V4wjPxPsbRzK/Govt-exceeds-201617-taxcollection-target-collects-Rs1710.html Accessed 5th March 2018.

${ }^{19} \mathrm{See}$ https://economictimes.indiatimes.com/news/economy/finance/gst-revenue-in-2018-19-to-grow-at14-16-sbi-ecowrap/articleshow/63176653.cms Accessed 6th March, 2018.
} 
ASARC Working Paper 2018/02

liberalization of domestic trade as compared to international trade. The GST has enabled the Indian economy to traverse a long distance in this direction. Further, the GST has the uniquely attractive feature that the shares of the central and state governments in the GST revenue are clearly delineated. This is crucial since some federal countries with long histories of GST along with one rate tax structure and unitary control have experienced disagreements about the disbursal of GST revenue when economic circumstances change. The implementation of the GST was not rushed since the country could carry on the momentum of demonetization and capitalize on the sharply rising digitization of transactions.

To say that demonetization and GST lowered the rate of growth is incorrect because the right counterfactual would have been what the growth rate would have been in the absence of demonetisation and GST. In any case, after one quarter of reduction, GDP growth is already on its way up (Table 3).

Thus, demonetization and GST have been momentous structural reforms in India. Although their implementation caused temporary hardships to many, faster, more transparent and inclusive economic growth lasting well into the future is now imminent.

\section{Augmenting employment and welfare programs}

The Modi government has sustained several old welfare programs and started new ones. Among the many programs that have been retained are the MGNREGP the Targeted Public Distribution Scheme, large numbers of input subsidies to farmers, some energy subsidies and others. An elaborate system of Direct Benefit Transfer (DBT) has been put in place, which deposits money directly into beneficiary bank accounts. The DBT has been instrumental in getting large numbers of intermediaries out of the system of subsidy payments. ${ }^{20}$

Moreover, nearly 10 million households were persuaded to give up their LPG subsidies. The money saved was transferred to the Ujjawala scheme wherein free LPG connections are given to women from poor households. In the 2018-19 budget 80

\footnotetext{
${ }^{20}$ Contrast this with the statement of former PM Rajiv Gandhi who once famously said that for every one $₹$ of subsidies only 15 paise reached the intended beneficiaries (the poor).
} 
million poor households were targeted to receive these connections. ${ }^{21}$ This is a remarkable turnaround as women in many of these households used to previously rely on firewood for cooking, which was harmful to their health. The Ujjawala scheme has also probably saved enormous amounts of public and private money that would be needed to treat conditions emanating from smoke inhalation from burning firewood.

In 2014 more than 18,000 Indian villages did not have electricity. Modi is committed to completing electrification of all villages by December 2018 of which more than 16,000 villages have already been electrified. The country is on track for electrification of all villages by December 2018. India is currently producing enough electricity for its needs but transmission and distribution concerns remain.

Other welfare schemes include Beti Bachao Beti Padhao (save the girl child, educate the girl child) and Swatch Bharat which targets the construction of toilets on a war footing. The latter is an important public health issue. As Spears et al. (2013) show open defecation is associated with stunting. In turn, stunting leads to lower school grades and lower productivity (Haile, et al.2016).

The Ayushman Bharat Scheme announced in the 2018-19 budget will provide health insurance to 100 million poor households (approximately 500 million people) who will be covered for up to ₹500,000 annually in medical costs. ${ }^{22}$ In addition, a number of insurance schemes - particularly for the poor - have been implemented. ${ }^{23}$ The government has promised to provide housing for all households by 2022 .

Farm distress has been addressed through a variety of measures including expanding crop insurance schemes, more smooth supply of fertilizers (particularly urea through neem coating), and help in meeting debt obligations. The 2018-19 budget stipulates that the Minimum Support Price paid by government agencies to farmers would be at least 150 $\%$ of their cost of production. The volume of institutional credit to the agricultural sector

\footnotetext{
${ }^{21}$ See https://economictimes.indiatimes.com/news/economy/finance/budget-allocation-to-womensschemes-hiked-4-to-rs-1-211-cr/articleshow/62745352.cms Accessed $2^{\text {nd }}$ March 2018.

${ }^{22} \mathrm{See}$ https://www.lawguage.com/government-schemes/ayushman-bharat-health-wellness-rashtriyaswasthya-sanrakshan Accessed $2^{\text {nd }}$ March 2018.

${ }^{23}$ See https://www.nhp.gov.in/national-health-insurance-schemes pg. Accessed $2^{\text {nd }}$ March 2018.
} 
would rise to ₹11 trillion, compared to ₹ 10 trillion in 2017-18. These steps could aid growth in the agricultural sector in 2018-19 and beyond.

Self-employment has been encouraged through Credit schemes such as the Prime Minister's Mudra Yojana to micro enterprises. By August 2017, as many as 55 million such self-employment opportunities had been created through this scheme. ${ }^{24}$ Similar self-employment opportunities have been opened up through programs such as Stand Up India, Start Up India and Skill India. PM Modi reported on $19^{\text {th }}$ January 2018 that in one year 7 million provident fund accounts had been added and over 100 million people have benefited from the Mudra Yojana.

These and several other welfare schemes that have not been mentioned here have had the impact that economic growth is now seen as being more inclusive than before.

\section{No long a member of the Fragile Five - the long term outlook for India}

In 2013, India was classified under a new unflattering category of countries - the Fragile Five. ${ }^{25}$ These countries ere vulnerable to economic slowdown and relied on foreign investments to cover current account deficits and finance growth and consequently began to see capital outflows following improvements in developed economies. After the coming to power of Modi, India's current account deficit and fiscal deficit have both improved substantially so that India has been able to shake off this unflattering characterization (Table 3).

A new "Make in India" program was initiated to increase manufacturing sector output. This has involved, inter alia, improving the climate for FDI inflows, facilitating permissions for establishment of new plants and equipment and augmenting existing plant capacity. some of their parts and accessories to $15 \%$ and on certain parts of TVs to $15 \%$.

\footnotetext{
${ }^{24} \mathrm{See}$ https://economictimes.indiatimes.com/news/economy/policy/narendra-modis-mudra-yojanagenerates-5-5-crore-jobs-says-report/articleshow/60435774.cms Accessed 6 ${ }^{\text {th }}$ March 2017. ${ }^{25}$ The term "Fragile Five" was coined by a Morgan Stanley financial analyst in August 2013. Other members of the Fragile Five included Turkey, Brazil, South Africa and Indonesia.
} 
There remains the challenge of reviving domestic investment. This is predominantly a legacy issue created largely by the vicious cycle of bad corporate debt) which got compounded by a sudden global slump and the economic disruptions triggered by a dose of structural reforms (like demonetization of high-value currencies and the roll-out of the GST) initiated by the NDA. Bad corporate debt and non-performing assets (NPAs) of banks are largely the consequence of some reckless lending in the face of the credit squeeze following the GFC and non-coordination between the disbursal of loans and the grant of various permissions. NPAs are being tackled by tightening of prudential norms and recapitalisation of some banks (particularly state-owned banks).

The recently announced budget for 2018-19 makes a concerted effort towards widening and deepening of bond markets. Large corporates are encouraged to use the bond market to finance one-fourth of their funding needs, the corporate bond market space is likely to be widened. This will further aid investment activity in India.

A strong effort is underway to improve the investment climate for Medium, Small and Micro Enterprises (MSME). ${ }^{26}$ Massive formalization of the MSME sector is taking place through demonetization and introduction of GST. A huge amount of data for the MSME sector is thus being collected which is facilitating this sector's transition to the GST regime. There are more manufacturing firms in the MSME sector than in medium or large firms' sector. Further, the MSME sector accounts for a large portion of manufacturing sector employment. With this in mind the 2018-19 Union Budget announced an allocation of ₹ 37.94 billion for giving credit support, capital and interest subsidy and innovations. Some tax concessions have also been announced for this sector.

In the intermediate to long runs, the institution of the GST will facilitate domestic investment. The removal of internal barriers will lower costs and promote economic and cost effective allocation of production units. This should facilitate both domestic investment and FDI. The contractionary effects of demonetization are now over and

${ }^{26}$ MSME is a firm with annual revenue less than ₹ 50 million. 
GST implementation is proceeding smoothly although some areas, particularly real estate and petroleum, are still outside the GST net.

The current phase of revival of the global economy is stimulative of Indian exports; however India's recent export performance has been lacklustre - particularly after the implementation of the GST. However, as the global economy grows India will also face some head winds. Global crude oil prices have climbed to around $\$ 70$ a barrel, higher than what most Indian policy makers assumed in their models. US interest rates have also begun to tighten. The yield on the two-year US treasury note is now at its highest level since September 2008, the month when Lehman Brothers collapsed. The yield curve has become steeper on expectations of higher inflation. The underlying reason for higher oil prices and US bond yields is that the global economy is in the midst of its best synchronized expansion since 2011. These would test the trade deficit and India's determination to not revert to the regime of administered pricing for large segments of the petroleum sector.

A surge in oil prices driven by supply constraints typically hurts economic activity over a long period of time. The impact is quite different in case the increase in oil prices is short-term and primarily because of higher demand. Oil importers typically experience a temporary increase in output as well as higher inflation over the longer term, i.e., a lot depends on whether the current increase in global oil prices is being driven by higher demand or lower supply (though the shale revolution makes the former a more likely candidate). That said, India is nowhere near the dangerous place it was in 2013.

However, to alleviate pressures from higher inflation and slight deterioration in trade and fiscal deficits private investment should rise sufficiently to increase productive capacity and the GST Network (GSTN) should swiftly address exporters' concerns. An emerging concern is the tariffs on steel and aluminium imposed by the US administration and the reciprocal measures that may be taken by other countries.

The recently announced budget for 2018-19 announced investment of ₹ 5.97 trillion in infrastructure for the next financial year. The commitment to smart cities continues. Achieving targets in these areas will help create a large number of job opportunities and facilitating commerce. 
To conclude, policy initiatives taken by the Modi government have done much to accelerate short-term economic growth and place the economy on a higher growth trajectory for the medium term. The government has also done much to make this growth relevant to satisfying citizens' needs and thus increased its appeal. 


\section{References}

Bagchi, A. (2002) "Fifty Years of Fiscal Federalism in India An Appraisal” Kale Memorial Lecture, Pune, Gokhale Institute of Politics and Economics.

Baru, S. (2014) The Accidental Prime Minister: The Making and Unmaking of Manmohan Singh, New Delhi: Viking.

Baru, S. (2016) 1991: How P.V. Narasimha Rao made history, New Delhi: Aleph Book Company.

Emran, M. and J. Stiglitz (2005) "On Selective Tax Reform in Developing Countries" Journal of Public Economics, 89, 599-623.

Haile, D. Nigatu, D., Garshaw, K. and H. Demelash (2016): "Height for Age z score and cognitive function are associated with academic performance among school children aged 8-11 years old" Archives of Public Health, vol. 74, no.17, DOI 10.1186/s13690-016-0129-9

Jha, R. and D.N. Truong (2015): "Estimates of Trade Misinvoicing and their macroeconomic outcomes for the Indian Economy" Review of Economics and Finance, vol. 5 , no. 2 ,

\section{Article ID: 1923-7529-2015-02-19-16}

Jha, R. (2018a) Facets of India's Economy and Her Society, vol. 1: Recent Economic and Social History and Political Economy. London: Palgrave Macmillan.

Jha, R. (2018b) Facets of India's Economy and Her Society, vol.2: Current State and Future Prospects. London: Palgrave Macmillan. 
Panagariya, A. (2018) "India: Three and a Half Years of Modinomics” Working Paper 2018-01, Columbia University, SIPA, Deepak and Neera Raj Centre on Indian Economic Policies.

Rogoff, K. (2016) The Curse of Cash, Princeton, NJ: Princeton University Press.

Spears D, Ghosh A, Cumming O (2013) Correction: Open Defecation and Childhood Stunting in India: An Ecological Analysis of New Data from 112 Districts. PLOS ONE 8(9): 10.1371/annotation/9ffcb740-f394-41af-bbbc-800c7cc25ea8.

https://doi.org/10.1371/annotation/9ffcb740-f394-41af-bbbc-800c7cc25ea8 View correction

Van Leemput (2016) A Passage to India: Quantifying Internal and External Barriers to Trade.

International Finance Discussion Papers, Number 1185, Board of Governors of the Federal Reserve System. 
ASARC Working Paper 2018/02

Table 1: India Corruption Perception Index

\begin{tabular}{|l|l|l|}
\hline Year & $\begin{array}{l}\text { Corruption Perceptions Index, } \\
\text { (higher index means less } \\
\text { corruption) }\end{array}$ & $\begin{array}{l}\text { Rank (lower rank means less } \\
\text { corruption) }\end{array}$ \\
\hline 2012 & 36 & \\
\hline 2013 & 36 & 94 \\
\hline 2014 & 38 & 85 \\
\hline 2015 & 38 & 76 \\
\hline 2016 & 40 & 79 \\
\hline
\end{tabular}

Source: Compiled from documents of Transparency International 
ASARC Working Paper 2018/02

Table 2: India's Performance in the World Bank's Ease of doing business Index

\begin{tabular}{|c|c|c|c|c|c|}
\hline & 2014 & 2015 & 2016 & 2017 & 2018 \\
\hline $\begin{array}{l}\text { Rank global } \\
\text { (DB18) }\end{array}$ & & 134 & 131 & 130 & 100 \\
\hline DTF global & & & 55.01 & 56.05 & 60.76 \\
\hline $\begin{array}{l}\text { Rank - Starting a } \\
\text { business }\end{array}$ & & & & & 156 \\
\hline $\begin{array}{l}\text { DTF - Starting a } \\
\text { business }\end{array}$ & 60.65 & 63.33 & 73.24 & 73.69 & 75.4 \\
\hline $\begin{array}{l}\text { Rank Dealing } \\
\text { with } \\
\text { construction } \\
\text { permits }\end{array}$ & & & & & 181 \\
\hline $\begin{array}{l}\text { DTF Dealing } \\
\text { with } \\
\text { construction } \\
\text { permits }\end{array}$ & & 36.17 & 36.17 & 36.17 & 38.8 \\
\hline $\begin{array}{l}\text { Rank getting } \\
\text { electricity }\end{array}$ & & & & & 29 \\
\hline $\begin{array}{l}\text { DTF getting } \\
\text { electricity }\end{array}$ & & 66.37 & 78.37 & 85.17 & 85.2 \\
\hline $\begin{array}{l}\text { Rank registering } \\
\text { property }\end{array}$ & & & & & 154 \\
\hline $\begin{array}{l}\text { DTF Registering } \\
\text { property }\end{array}$ & & 51.29 & 46.83 & & 47.08 \\
\hline $\begin{array}{l}\text { Rank protecting } \\
\text { Minority } \\
\text { Investors }\end{array}$ & & & & & 29 \\
\hline $\begin{array}{l}\text { DTF Protecting } \\
\text { Minority } \\
\text { investors }\end{array}$ & 65 & 65 & 65 & 65 & 75 \\
\hline $\begin{array}{l}\text { Rank Paying } \\
\text { taxes }\end{array}$ & & & & & 119 \\
\hline $\begin{array}{l}\text { DTF Paying } \\
\text { Taxes }\end{array}$ & & & 44.16 & 47.67 & 66.06 \\
\hline $\begin{array}{l}\text { Rank - Trading } \\
\text { across borders }\end{array}$ & & & & & 146 \\
\hline $\begin{array}{l}\text { DTF Trading } \\
\text { across borders }\end{array}$ & & 56.45 & 56.45 & 57.61 & 58.56 \\
\hline $\begin{array}{l}\text { Rank - } \\
\text { Enforcing } \\
\text { contracts }\end{array}$ & & 36.13 & 38.9 & 40.76 & 164 \\
\hline $\begin{array}{l}\text { DTF Enforcing } \\
\text { contracts }\end{array}$ & & & & & \\
\hline $\begin{array}{l}\text { Rank - } \\
\text { Resolving } \\
\text { insolvency }\end{array}$ & & & & & 103 \\
\hline $\begin{array}{l}\text { DTF - Resolving } \\
\text { insolvency }\end{array}$ & 32.4 & 32.6 & 32.5 & 32.7 & 40.7 \\
\hline
\end{tabular}

Source: World Bank database

N.B. DTF $=$ Distance to Frontier, Frontier being 100 or best practice. 
ASARC Working Paper 2018/02

Table 3: Key Macroeconomic Parameters of the Indian Economy (Percent, unless stated otherwise)

\begin{tabular}{|c|c|c|c|c|c|c|c|}
\hline Year & $2012-13$ & $\begin{array}{l}2013- \\
14\end{array}$ & $2014-15$ & $2015-16$ & $2016-17$ & $2017-18$ & $\begin{array}{l}2018-19 \\
\text { (forecast } \\
\text { ) }\end{array}$ \\
\hline $\begin{array}{l}\text { GVA } \\
\text { growth }\end{array}$ & 5.42 & 6.05 & 7.23 & 8.1 & 7.1 & 6.1 & \\
\hline $\begin{array}{l}\text { Real GDP } \\
\text { growth }\end{array}$ & 5.46 & 6.39 & 7.51 & 8.2 & 7.1 & 6.75 & $\begin{array}{l}7 \text { to } 7.5 \\
\text { (7.4) }\end{array}$ \\
\hline $\begin{array}{l}\text { Per capita } \\
\text { GDP at } \\
2011-12 \\
\text { prices (₹.) }\end{array}$ & $\begin{array}{l}74,599.3 \\
3\end{array}$ & $\begin{array}{l}78,348 \\
.\end{array}$ & $\begin{array}{l}83,091.3 \\
5\end{array}$ & $\begin{array}{l}88,746.2 \\
6\end{array}$ & $\begin{array}{l}93,887.6 \\
5\end{array}$ & $\begin{array}{l}98,673.0 \\
0\end{array}$ & \\
\hline $\begin{array}{l}\text { Population } \\
\text { (million) }\end{array}$ & 1,235 & 1,251 & 1,267 & 1,283 & & & \\
\hline $\begin{array}{l}\text { Fiscal } \\
\text { Deficit as } \\
\% \text { of GDP }\end{array}$ & 4.89 & 4.4 & 4.1 & 3.9 & 3.5 & 3.5 & 3.3 \\
\hline $\begin{array}{l}\text { Exports as } \\
\% \text { of GDP }\end{array}$ & 24.85 & 25.18 & 23.86 & 20.89 & & & \\
\hline $\begin{array}{l}\text { Imports as } \\
\% \text { of GDP }\end{array}$ & 31.25 & 26.98 & 25.33 & 22.05 & & & \\
\hline $\begin{array}{l}\text { Current } \\
\text { Account } \\
\text { Deficit as } \\
\% \text { of GDP } \\
\text { (calendar } \\
\text { year) }\end{array}$ & 5.004 & 2.64 & 1.34 & 1.07 & 0.53 & (a) & \\
\hline $\begin{array}{l}\text { Foreign } \\
\text { exchange } \\
\text { Reserves (\$ } \\
\text { billion) }\end{array}$ & 292.0 & 304.2 & 341.6 & 360.2 & 370.0 & 402.0 & \\
\hline $\begin{array}{l}\text { CPI } \\
\text { Inflation } \\
(\%)\end{array}$ & 9.9 & 9.4 & 5.9 & 4.9 & 4.5 & 2.5 & \\
\hline $\begin{array}{l}\text { Index of } \\
\text { government } \\
\text { final } \\
\text { consumptio } \\
\mathrm{n} \\
\text { expenditure } \\
2011-12= \\
100\end{array}$ & 100.6 & 101.2 & 110.9 & 114.6 & & & \\
\hline $\begin{array}{l}\text { Private } \\
\text { final } \\
\text { consumptio } \\
\mathrm{n}\end{array}$ & 105.5 & 113.2 & 120.2 & 127.5 & & & \\
\hline
\end{tabular}


ASARC Working Paper 2018/02

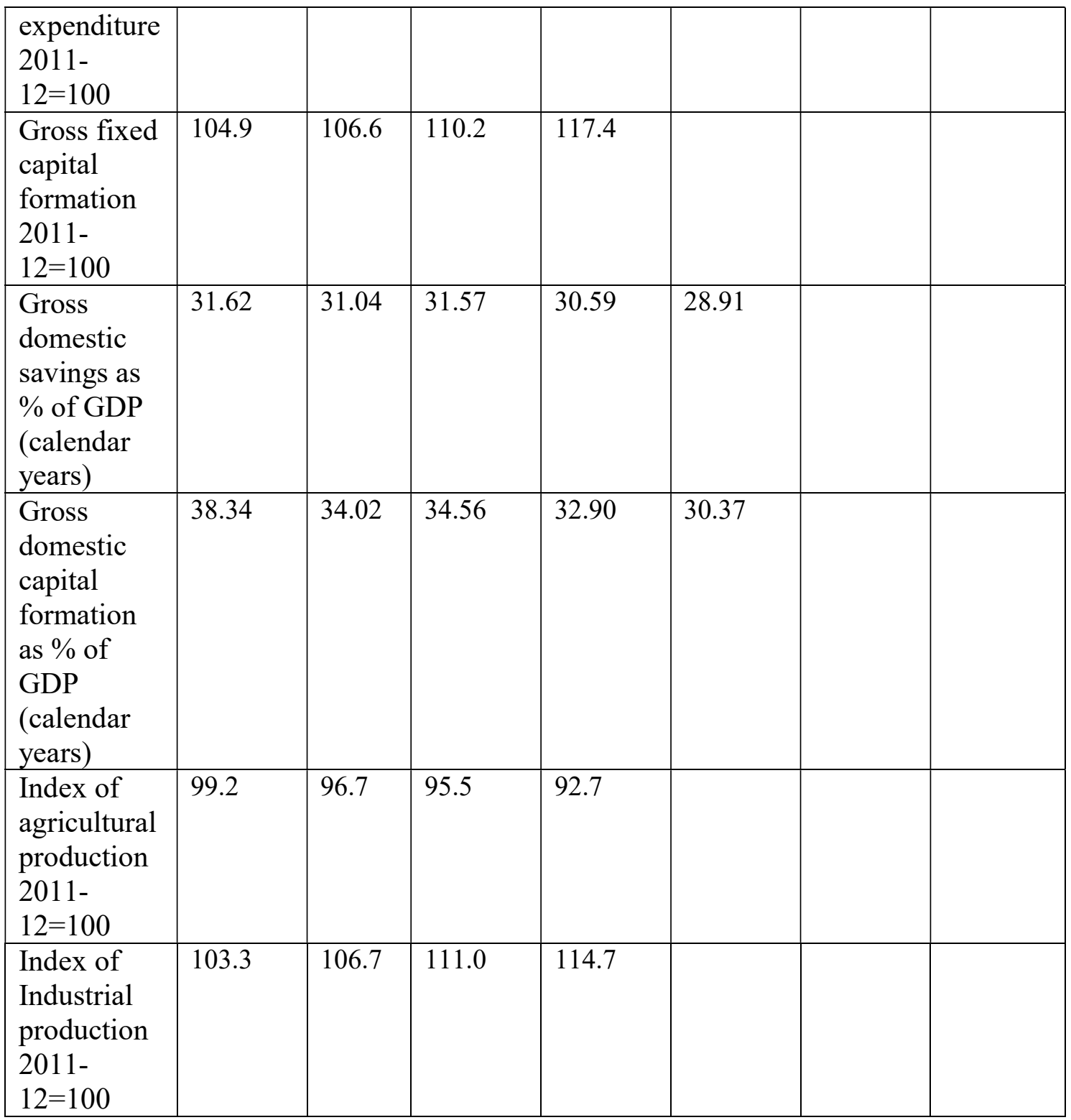

Sources: For 2012-13 to 2014-15: Author's calculation based on data from Central Statistical Office (CSO), Government of India; For 2015-16 final estimate, CSO; For 2016-17 revised estimate CSO, for 2017-18 GVA figure from CSO and GDP figure from Economic Survey, 2018, Ministry of Finance, Government of India, For 2018-19, first figure derived from Economic Survey, 2018; figures in parenthesis are estimates of the ADB and the IMF for the calendar year 2018, Current account deficit, savings as percentage of GDP and capital formation as percentage of GDP figures refer to calendar years and are from World Bank World Development Indicators. @ India's current account deficit was $1.5 \%$ of GDP in 2017-18.

N.B. The IMF forecasts India's growth rate to rise to above $8 \%$ by 2022 , the current horizon for its forecast. 
ASARC Working Paper 2018/02

Table 4: Indicators of Connectivity

\begin{tabular}{|l|l|l|l|l|l|l|l|}
\hline \multicolumn{7}{|c|}{ Increase in railway tracks (km) } \\
\hline & $2011-12$ & $2012-13$ & $2013-14$ & $2014-15$ & $2015-16$ & $2016-17$ \\
\hline New Lines & 400 & 352 & 360 & 380 & 813 & 953 \\
\hline $\begin{array}{l}\text { Gauge } \\
\text { Conversion }\end{array}$ & 675 & 725 & 750 & 880 & 1,042 & 1,020 \\
\hline Doubling & 400 & 430 & 500 & 723 & 973 & 882 \\
\hline Total & 1,475 & 1,507 & 1,610 & 1,983 & 2,828 & 2,855 \\
\hline \multicolumn{7}{|c|}{ Increase in road length (km) } \\
\hline $\begin{array}{l}\text { National } \\
\text { Highways } \\
\text { (construction) }\end{array}$ & $2011-12$ & $2012-13$ & $2013-14$ & $2014-15$ & $2015-16$ & $2016-17$ \\
\hline $\begin{array}{l}\text { Average road } \\
\text { constructed/day } \\
\text { under PMGSY } \\
\text { (km.) }\end{array}$ & 8,013 & 5,732 & 4,260 & 4,410 & 6,061 & 8,231 \\
\hline $\begin{array}{l}\text { Road length } \\
\text { Completed } \\
\text { under PMGSY } \\
\text { (km.) }\end{array}$ & 30,994 & 24,161 & 25,316 & 36,337 & 36,449 & 47,447 \\
\hline $\begin{array}{l}\text { Funds released } \\
\text { to states (₹ } \\
\text { crores) }\end{array}$ & 15,809 & 4,389 & 5,360 & 9,960 & 15,187 & 16,508 \\
\hline
\end{tabular}

Source: Various government documents 